\title{
INSTITUCIONALIZAÇÃO ESCOLAR NA CIDADE DE OUVIDOR-GO - 1949-1971
}

\author{
Reni Maria Jacob ${ }^{1}$ \\ Wolney Honório Filho ${ }^{2}$
}

\section{INTRODUÇÃO}

Um fator favorável do município de Ouvidor $^{3}$ sempre foi a sua localização estratégica. Seus limites com Minas Gerais e o acesso relativamente facilitado à capital do Estado de Goiás e à Capital Federal lhe facilitou condições de progresso. Assim, "o papel redentor da educação, recorrente na discursividade das elites nacionais, apropriado pelos dirigentes goianos: de que, educar significava moralizar o povo, incutir-lhes hábitos saudáveis como amor ao trabalho, à higiene, a Deus, e à pátria, retirá-lo da ignorância” (PINTO, 2012, p. 326) também figurou com facilidade no pensamento das autoridades locais e nos visionários que residiam na região rural de Catalão. Diante disso, a criação do primeiro Grupo Escolar Dr. Pedro Ludovico Teixeira foi apropriada para Ouvidor, distrito de Catalão - GO, na época, mesmo que este não estivesse apto a sustentar uma escola progressista, como era a imagem dos grupos escolares de então.

Este texto objetiva historicizar o processo de institucionalização do primeiro Grupo Escolar da Cidade de Ouvidor - GO, de 1949 a $1971^{4}$. A data define o recorte temporal estabelecido entre o ano de criação do Grupo Escolar Dr. Pedro Ludovico Teixeira até a promulgação da Lei no 5.692 de 11 de agosto de 1971 - DOU de 12/8/71 - Lei de Diretrizes de Bases, que extinguiu os grupos escolares no Brasil e Implantou o Sistema de Ensino de $1^{\circ}$ e $2^{\circ} \mathrm{Grau}$.

O que é uma Instituição Escolar? Seria o que os relatos dizem o que ela é? Esta é uma questão que nos leva a outra: como estudar/pesquisar uma Instituição Escolar? Nosella e Buffa (2009) dizem que a pesquisa sobre instituições escolares amplia os horizontes do conhecimento educacional.

\footnotetext{
${ }^{1}$ Mestre em Educação e professora da Rede Municipal de Ouvidor-GO. Email: renijacob2010@gmail.com

${ }^{2}$ Doutor em História e Professor da Unidade Acadêmica Especial - Educação - Universidade Federal de Goiás Regional Catalão, onde atua no Programa de Mestrado em Educação e no Curso de Pedagogia. É líder do NEPEDUCA - Núcleo de Estudos e Pesquisas em Educação de Catalão. E-mail: whonoriof@gmail.com

${ }^{3}$ Município da Região sudeste de Goiás, emancipado pela Lei no ${ }^{824}$, de 19 de outubro de 1953.

${ }^{4}$ Este texto é resultado do Projeto de Pesquisa "Narrativas do Primeiro Grupo Escolar do Município de Ouvidor - GO: 1949-1971". O mesmo foi submetido e aprovado na Plataforma Brasil onde o CONEP é representado pelo CEP de Goiás que designou o número 39328714.1.0000.5083.
} 
Saviani, por sua vez, atesta três características ao estudo das instituições escolares: materialidade, representação e apropriação:

Por materialidade se está entendendo a escola instalada (o instituído) em sua visibilidade mais imediata, envolvendo as condições físicas no seu aspecto arquitetônico (o prédio) com seus equipamentos, incluindo o material didático, e sua estrutura organizacional [...] O suporte físico das práticas educativas. A representação traduziria o sentido atribuído ao papel desempenhado pela instituição escolar, envolvendo a tradição (memórias), a bibliografia selecionada, a prefiguração (planejamento) [...] A apropriação por sua vez corresponderia à materialidade-conteúdo em ato, compreendendo as práticas pedagógicas [...] Definindo-se a identidade dos sujeitos e da instituição e seus respectivos destinos de vida [...] Assim, será necessário, na análise das instituições, correlacioná-las com as condições sociais nas quais emergiram segundo contextos históricos-geográficos determinados [...] (SAVIANI, 2007, p 2425.)

Nesta perspectiva, uma instituição escolar, o "suporte físico das práticas educativas", como a adjetiva Saviani, o seu estudo e/ou pesquisa está relacionado tanto com a sua materialidade interna, ou seja, professores, servidores e alunos, como também documentação escrita, arquitetura, etc., e as condições sócio - históricas que permeiam a instituição.

Aqui, neste caso, exploramos o enfoque biográfico e narrativo conferido a uma instituição escolar. Conforme Bolívar (2014, p.330) “el enfoque biográfico y narrativo de la organización oferece un modo alternativo para describir, analizar y teorizar los processos y prácticas educativas em la escuela". Ou seja, Bolívar (2014) no artigo "Narrar la organización educativa: memoria institucional y constitución de la identidade" apresenta-nos uma instigante abordagem teórico metodológica, sobre a história das instituições escolares, através do enfoque biográfico narrativo. Este autor mostra que a história/biografia de uma instituição se constitui como um objeto de estudo, haja vista que cada uma delas se desenvolve e se organiza de forma singular; ele entende que a história das instituições, embora seja socialmente constituída, ou seja, parte de um projeto exterior, tem a sua própria biografia a partir das singularidades de cada uma delas:

Comprender el centro escolar como uma realidade constuida socialmente, conduce a verlo como uma instituición que tiene su propia historia, que - por eso mismo - ha generado estructuras, roles, patrones de acción, significados, rituales, etc.; es decir, su cultura organizativa. Las escuelas, em lugar de realidades objetivas, tienen su propia biografia institucional, historia y processos de desarrollo, que pueden ser objeto de estúdio. (BOLÍVAR, 2014, p. 332).

história do Grupo Escolar Dr. Pedro Ludovico Teixeira está relacionada com as tramas políticas locais, regionais e nacionais. A sua identidade, ao mesmo tempo em que surgiu de um projeto nacional se fortaleceu com as conquistas diárias que a fizeram acontecer.

Bolívar (2014) esclarece que:

las organizaciones, como construcciones sociales, están constituídas por conjuntos de relatos colectivos, vividos y transmitidos que circulan en la cultura interior y en la imagem exterior. Las narrativas, como nudos estratégicos en la construcción del sentido comunitário, son los médios por los que se manifiesta la memoria institucional, la historia y se constituye la identidad organizacional y professional (BOLÍVAR, 2014, p.330). 
A realidade organizacional, ou a instituição escolar, está colada ao modo como os indivíduos a percebem, vivem ou expressam. E esses modos se apresentam tanto em documentos escritos, quanto em entrevistas que buscam evidenciar memórias do primeiro Grupo Escolar de Ouvidor.

\section{O PROCESSO FUNDADOR DO PRIMEIRO GRUPO ESCOLAR DE OUVIDOR - GOIÁS.}

A população do Centro-Oeste e de Goiás sofreu um acréscimo respeitável entre os anos de 1920 e 1950, conforme podemos notar na tabela a seguir. Ouvidor certamente acompanhou esse ritmo, embora seus dados populacionais encontrados sejam todos posteriores ao ano de 1950. Estima-se que antes havia bem menos pessoas residindo por ali e que só a partir de 1922, com a construção da Estação Ferroviária e com a chegada da esperança de comunicação e transporte mais eficazes, as pessoas fossem atraídas para o povoado. A tabela 01 mostra que entre 1920 e 1950 a população da região Centro Oeste cresceu aproximadamente 50\%, próximo ao que aconteceu com o Estado de Goiás, que cresceu um pouco mais de 50\%. Apesar de não ter sido possível encontrar fontes estatísticas referentes ao aumento populacional de Ouvidor para estabelecer uma comparação exata através de números anteriores à institucionalização do Grupo Escolar Dr. Pedro Ludovico Teixeira, em 1949, presume-se que o que ocorreu em Goiás foi proveniente do crescimento populacional, principalmente das regiões que foram beneficiadas pela abertura dos trilhos, da Rede Mineira de Viação (RMV), inaugurada em 11/11/1942, que cortou o território goiano e passou pelo município de Ouvidor, e mais tarde a RMV foi incorporada à RFFSA (Rede Ferroviária Federal Sociedade Anônima) cuja criação data de autorização da Lei no 3.115, de 16 de março de 19575.

Tabela 01: Crescimento populacional do Centro Oeste e Goiás entre 1920 e 1950.

\begin{tabular}{|c|c|c|c|}
\hline \multicolumn{4}{|c|}{ HABITANTES POR LOCALIDADE } \\
\hline ANO & $\begin{array}{c}\text { REGIÃO CENTRO } \\
\text { OESTE }\end{array}$ & GOIÁS & $\begin{array}{c}\text { Distrito } \\
\text { de OUVIDOR }\end{array}$ \\
\hline 1920 & 758.531 & 511.919 & - \\
\hline 1940 & 1.258 .679 & 826.414 & - \\
\hline 1950 & 1.532 .924 & 1.224 .92 & 3.458 \\
\hline
\end{tabular}

Fonte: organizado pelos autores- SEGPLAN- 2013 e IBGE.

Com a população crescendo desde a chegada dos trilhos, o primeiro movimento em direção à conquista do grupo escolar aconteceu concretamente no dia sete de abril de 1949. Neste dia, o deputado Diógenes Dolival Sampaio, inspetor escolar, visitou o povoado de Ouvidor trazendo nas

\footnotetext{
${ }^{5}$ Ver em http://vfco.brazilia.jor.br/RFFSA/RFFSA-ferrovias-formadoras.shtml. Acesso em 19-04-2016.
} 
mãos um ofício do Secretário da Educação de Goiás, Dr. Hélio Seixo de Brito, assessor do governador Jerônimo Coimbra Bueno. Nesta recepção estavam, além das pessoas que assinaram a ata, os alunos da escola, que deviam ser em um número aproximado de setenta crianças ${ }^{6}$.

A abertura do livro e a primeira ata foram redigidas pela professora Lenita Pires Ribeiro. Além dela, mais dois professores fizeram parte deste feito, o professor Abílio José Pires, pai da redatora, e a professora Alexandrina Vicente. Provavelmente, outros cidadãos compartilhavam o memorável dia, embora nem todos assinassem a ata. Um exemplo é que o Sr. Antônio Ferreira Goulart, subprefeito municipal, foi mencionado e estava presente, mas não aparece no rol dos assinantes. As assinaturas foram iniciadas pelo visitante, seguido pela redatora e o primeiro professor do local, autoridades e demais presentes dispostos na seguinte ordem: Diogenes Dolival Sampaio, Lenita Pires Ribeiro, Abílio José Pires, Antenor Firmino, Adalardo Antônio de Mesquita, Hélio Ferreira Goulart, Vigilato Evangelista Pereira, Alexandrina Vicente da Silva, José Antônio dos Santos e Valmir Paranhos Guimarães.

Segundo depoimentos da redatora ${ }^{7}$ dessa primeira ata, a professora Lenita Pires da Silva, pessoa que ainda vive e foi entrevistada para a reconstrução da história do Grupo Escolar de Ouvidor, o interesse político do evento citado reuniu, além dos visitantes vindos de outros locais, os professores, e pessoas do povoado com profissões alheias à educação, representantes dos comerciantes, de fazendeiros, dos políticos e outras autoridades locais.

O prédio onde ocorreu o evento mencionado na Ata, era o Galpão do professor Abílio, construção ao lado de sua residência, pois ele, sua filha Lenita e a sobrinha Alexandrina exerciam as suas funções de professores no local, ou seja, na Rua São José, s/n. e essa escola era denominada Escola Rural Número 01. Antes desta reunião ainda não se falava em grupo escolar. Assim, obviamente não existia construção destinada ao seu funcionamento.

Embora esta primeira ata não tenha registrado com clareza que a pauta da reunião era a institucionalização do primeiro grupo escolar de Ouvidor, o teor do ofício enviado pelo Secretário de Educação, Hélio Seixo de Brito, seria impulsionar a abertura do grupo. Mas, o mesmo não foi transcrito na pauta. Porém, a confirmação veio depois, quando encontramos a Lei de criação do Grupo de Ouvidor com a data retroativa de 1949. Ou seja, no período exato dos acontecimentos descritos nos acervos documentais da primeira Ata do Grupo.

\footnotetext{
${ }^{6}$ Ver: primeira ata do Grupo Escolar Pedro Ludovico. Acervo documental da Escola da Escola Estadual Dácio Amorim Fonseca. Cabe observar que o Grupo se transformou posteriormente na Escola Estadual Dácio Amorim Fonseca.

${ }^{7}$ Entrevista SILVA, 2015).
} 
O processo de institucionalização do grupo foi lento. Apesar da Lei 442, de 8 de dezembro de 1949, sobre seu funcionamento, o registro seguinte no mesmo livro de atas se refere a uma visita de inspeção oito meses depois, em outubro de 1949, quando o inspetor escolar fez um curto relatório da Inspeção nos termos a seguir:

Tendo visitado a Escola rural $n^{\circ} 1$ do Povoado de Ouvidor, onde lecionam os professores Abílio José Pires e Lenita Pires Ribeiro, notei que estava a escola em bom funcionamento, com uma matrícula de 35 alunos todos com boa ordem. Sendo esta a minha visita deste ano, notei que todos estão com bom aproveitamento.

Ouvidor, 5 de Outubro de 1949.

Jaime Loureiro dos Santos

(Livro $1^{\mathrm{a}}$ ata de fundação: 30-03-1954, p.3/ 07-04-1949).

O pequeno relatório de Jaime Loureiro dos Santos, ao deixar a sua mensagem de aprovação da escola do Professor Abílio, possivelmente já demonstra que era uma sala considerada o início do grupo escolar. E, apesar de tudo indicar que os alunos continuaram a estudar no Galpão de sempre, talvez até a construção do novo prédio, não existe nenhum vestígio documental que nos dê essa certeza, e as memórias e relatos orais são ineficazes sobre o assunto. $\mathrm{O}$ fato é que no histórico do memorial da própria instituição existe uma pista que reforçou a ideia de que esta visita à escola do professor já teria sido considerada uma visita ao grupo escolar. Tivemos acesso a esse documento que revela a seguinte mensagem: "em 1949 foi criado pela Lei no 442 a instalação do Grupo Escolar de Ouvidor. [...] Eram professores na época o Sr. Abílio Pires e a Sr. ${ }^{a}$ Alexandrina Vicente da Rocha que ficou também responsável pela administração de 1949 a 1960.” (Histórico - Memorial da Escola Estadual Dácio Amorim Fonseca).

Outro indício de que é a versão mais condizente com a história do início da institucionalização do grupo é a redação da primeira ata de que se tem notícias, quando, no segundo parágrafo, menciona-se a quantidade de alunos matriculados, que coincide com a soma dos alunos do Galpão do professor Abílio com os da professora Sarah, registrados em outro livro do mesmo acervo.

A ausência da professora Sarah na reunião, descrita na ata, não apresenta justificativa, mas o seu local de trabalho naquele tempo era outra sala rural, ou seja, uma escola isolada. Bretas (1991) se refere às várias escolas isoladas, que reunidas davam origem à novidade apresentada na educação brasileira pelos republicanos dizendo que,

A grande novidade da reforma foi a introdução do Grupo Escolar em Goiás. Instituição que já era comum em outros estados da federação. [...] existiam várias escolas isoladas, funcionando 
uma, duas ou três delas em cada freguesia, instaladas nas residências dos próprios professores ou em casas alugadas. Começou-se então a pensar em reunir todas as escolas de uma cidade, de uma freguesia ou bairro populoso em um só edifício [...] especialmente construído para tal fim, e em cada sala colocar uma mesa isolada com seu professor e alunos, formando, assim, um centro de ensino, como se fazia em outros países. (BRETAS, 1991, p. 506).

Enfim, o grupo foi institucionalizado no papel pela Lei 442, mas, na prática, continuou a funcionar nas escolas isoladas por um bom tempo ainda, pelo menos entre 1949 e 1959, o barracão da Escola Rural $n^{\circ} 01$ continuou ativo. No início, por não ter outro local para o funcionamento das aulas. Depois, quando foi erguido o edifício para o funcionamento do Grupo escolar, por conta do mesmo não suportar o número de salas exigidas pela organização da época, ou seja, eram apenas duas, as salas do novo Grupo. Assim, não eram suficientes ao número de séries para serem distribuídas para as mesmas.

A ata referida acima mostra uma comunidade reunida em torno de uma visita de um político de renome na região e que também era inspetor escolar. A oportunidade não foi desprezada pelos interessados, inclusive com a fala dos professores que nenhum material tinha sido doado aos alunos. Esta alegação mais adiante, na mesma ata, foi corrigida da seguinte forma: "Em tempo: referindo-se ao material escolar não recebido, disseram os professores que se referem aos do Estado e não do Município". Assim, fizeram questão de reforçar que o Estado de Goiás não fornecia nenhuma ajuda àquela escola, mas que a prefeitura lhes dava o apoio necessário.

O Grupo Escolar de Ouvidor possuía apenas duas salas8. Mas, apesar de modesto, viria a ser mesmo o centro de ensino do distrito, pois reuniu no mínimo três escolas em funcionamento: a Escola Rural $n^{\circ}$ 1, Escola Rural $n^{\circ} 2$ e a Escola de Alfabetização de Adultos e Adolescentes que estava em atividades no período noturno. Segundo Bretas (1991, p.506), várias seriam as vantagens de um Grupo: "facilitaria a inspeção e administração do ensino, poder-se-ia juntar todos os alunos e distribuí-los em classes, cada classe reunindo os alunos da mesma idade e do mesmo adiantamento, garantindo, assim, certa homogeneidade".

Mas, já sabemos que esta reunião no Grupo Escolar de Ouvidor não aconteceu de imediato, pois duas salas não seriam suficientes para abrigar todos os alunos que o Distrito já reunia em suas atividades escolares.

O título abaixo reúne alguns elementos que elucidará os acontecimentos que travaram esta institucionalização de imediato.

\footnotetext{
${ }^{8}$ Conforme Ata de Instalação do Grupo Escolar de Ouvidor, pgs. 04 e 05 /1954.
} 


\section{EM PASSO LENTO SEGUE O GRUPO ESCOLAR DE OUVIDOR.}

Para explicar a lentidão com que o primeiro grupo escolar de Ouvidor se estabeleceu e ganhou a sua identidade própria, recorremos em primeiro lugar às políticas públicas educacionais do país, que pulverizaram as responsabilidades sobre as instituições, de forma a instalar uma superposição entre poderes. Este processo retardava a criação dos grupos escolares, detendo "a gestão dos sistemas, a criação de escolas, a nomeação de professores, os recursos arrecadados, que permaneciam nas mãos do governo central, que dividiria os custos pesados de edificações com os municípios" (PINTO, 2013, p. 336-338). Segundo este autor,

Se em nível federal, a educação pouco ocupou a agenda política nacional, a preocupação com os gastos públicos, a condição dos prédios e casas escolares, a criação de novas edificações, a formação escolarizada e a exigência da diplomação do corpo docente, a insistência na reforma (recorrente) do ensino primário e na escola normal, todos estes aspectos demonstravam a centralidade da escolarização (PINTO, 2013, p. 336).

Porém, apesar de central, havia uma morosidade, como é o caso da demora percorrida desde o momento da assinatura da Lei que criou a escola em Ouvidor até o dia em que finalmente o primeiro grupo escolar seria instalado em condições de funcionamento adequadas.

No que diz respeito à centralização a que se referem os autores, mesmo que a educação tivesse a sua organização na época submetida ao governo federal e estadual, em Ouvidor ela não ocorreu. Diante da necessidade latente do povoado, o povo não podia esperar pela boa vontade dos governantes, pois isso significava um atraso na demanda, se as salas isoladas não estivessem em funcionamento.

Outro problema é que Ouvidor não dispunha de professores qualificados, não tinha um edifício suntuoso, não possuía a pedagogia do método intuitivo ou a lição das coisas, mas como agravante, ainda vivenciava um gritante analfabetismo em seu seio. Assim, o local não dispunha de tempo para se acomodar à espera das benesses prometidas com as reformas inacessíveis a centros modestos e inoperantes frente ao olhar daqueles que comandavam os destinos administrativos do país.

Os documentos demonstram que, apesar da falta de condições equiparadas às reformas educacionais do momento, a instituição pesquisada possuía credibilidade junto aos inspetores do Estado. O que contrariava a centralização da educação aos limites dos governantes, que, de certa forma, impedia o deslanchar cultural de uma sociedade hodierna como o Brasil que, sendo colônia e dependente por tantos anos, aprendia no berço da liberdade a caminhar com seus próprios pés. Assim, Goiás e Ouvidor na conquista dos seus grupos escolares contribuíram com a elevação dos 
números de alfabetizados e com o desenvolvimento cultural. Mas a disputa pelo orçamento era desigual e injusta, "ao mesmo tempo, se prestavam a ser instrumentos de barganha, conferindo aos dirigentes públicos maior visibilidade política embora fosse menor o alcance social" (PINTO, 2013, p. 340).

Os professores leigos ${ }^{9}$ que atuaram no primeiro grupo escolar de Ouvidor encorpavam a certeza de que "o Estado republicano manteve algumas poucas instituições modelares que simbolizava o desejo fáustico de inovação e propagandeavam o novo regime, enquanto boa parte do ensino público padecia de enormes problemas" (SOUZA, 1998, p. 69). E os problemas que a escola de Ouvidor apresentava não eram suscetíveis a mudanças imediatas.

Portanto, a verdadeira implantação do tão sonhado grupo escolar teve o seu tempo de espera. Sem querer, contudo, "subestimar a importância que a exigência da formação para o exercício docente teve para a profissionalização do magistério. Ser professora, ser professor, tornava-se uma profissão especial [...] significou uma nova forma de ser no mundo e novas possibilidades de inserção social" (SOUZA, 1998, p. 69). O esforço pessoal desses professores não substituía a necessidade de uma boa formação, mas possibilitou para muitos de seus alunos não a inserção, mas a ascensão $\operatorname{social}^{10}$.

Elucidados os pontos principais de referência da delonga para a instalação do primeiro grupo escolar fundado em 1949, no ainda Distrito de Ouvidor, passamos a analisar a ata denominada "Ata de Instalação do Grupo Escolar de Ouvidor”. Ela teve como cenário o dia trinta de março de mil novecentos e cinquenta e quatro. Mais precisamente cinco anos após a Lei de criação do referido Grupo.

O local de funcionamento do Grupo já tinha uma sede própria, e o prédio novo, construído para esta finalidade, preenchia os requisitos de criação dos grupos escolares propostos pela legislação. Mas, os professores ainda não possuíam formação no curso normal e o número de alunos estava longe dos 140 necessários para a criação de um grupo escolar. Mesmo assim, a centralização do ensino já estava em cordas bambas, talvez pela inoperância do Estado que não conseguia tomar

\footnotetext{
${ }^{9}$ Leigos aqui está no sentido de professores não habilitados. No Brasil, a existência de professores leigos era comum, principalmente nas regiões Norte, Nordeste e Centro-Oeste, onde muitos deles estudaram apenas até a $4^{\mathrm{a}}$ série e a maior parte não terminou o ensino fundamental (antigo $1^{\circ}$ grau). Como era o caso do grupo em estudo.

${ }^{10}$ Nas entrevistas, alguns professores relataram como se orgulham por seus alunos terem ascendido socialmente pela influência da base primária, indo concorrer a vagas em lugares distantes para cursos mais adiantados e alcançando pleno sucesso.
} 
as providências suficientes para a disseminação da escola pública. Fato é que permitiram o funcionamento do Grupo.

Estiveram presentes na Implantação do Grupo representantes do poder público estadual, local, cidadãos e alunos: prefeito municipal de Ouvidor, Idalício da Silva, Senhor Inspetor escolar, João de Serqueira Netto, Sr. Theobaldo Ayres, Sr. Manoel de Sena Pereira, Pedro Mendes dos Santos, Almerinda Magalhães Arantes, Maria do Rosário Ayres, Adalardo Antônio de Mesquita, Idileno da Silva, Benjamim Antônio Costa, Bernardino Senna Netto. Também esteve no evento, o professor Abílio José Pires, Alexandrina Vicente da Rocha, Ana Rosa de Lima e Alméria de Paiva Mesquita. Para marcar a relevância da cerimônia de abertura, o Hino Nacional brasileiro foi entoado por todos e, em prosseguimento, fez-se a leitura do Decreto de 22 de março de 1954, assinado pelo governador Dr. Pedro Ludovico Teixeira:

O governador do Estado de Goiás usando de suas atribuições legais e de acordo com a Lei n.591 de 14 de novembro de 1951 resolve marcar para o dia 30 de março do corrente a instalação do Grupo Escolar de Ouvidor, criado pela Lei no 442 de 8 de dezembro de 1949.

Palácio do Governo do Estado de Goiás, em Goiânia aos 22 de março de 1954, 65ª República:

Assinado por

Dr. Pedro Ludovico Teixeira. (Parte transcrita na ata do Grupo, p.4).

Embora não estivesse presente, o deputado Wison da Paixão (PSD - Partido Social Democrático) foi citado na cerimônia como patrono da criação do grupo na Assembleia Legislativa, reforçando que o evento aconteceu também pelo desejo do governador, frente aos apelos do povo da cidade de Ouvidor. Interessante destacar que, na oportunidade, a deputada Almerinda Magalhães não perdeu a oportunidade de reforçar os ideais de educação do presente, dizendo que "a educação primária é a base fundamental não só da instrução, como desenvolvimento e progresso de uma comuna"11.

No movimento político da cidade se iniciava um processo de transformações. Não esteve presente no acontecimento a família Goulart, que marcava força em um dos partidos políticos locais e aparecia na ata anterior. Pelo que se sabe pelas narrativas orais e memória dos entrevistados, o Sr. Manoel de Sena Pereira, figurante nas páginas do documento analisado, foi um forte concorrente da citada prole e, por sua vez, estava ausente na primeira reunião de implantação do grupo. Intuímos que os representantes de partidos adversários não frequentavam os mesmos locais.

\footnotetext{
${ }^{11}$ Fala da deputada constante no verso da página 04, no livro da $1^{a}$ ata de fundação: 07/04/1949.
} 
O entusiasmo pela instalação permaneceu por certo tempo. Decorridos menos de trinta dias, o novo grupo escolar recebeu a visita do inspetor estadual, que foi registrada na página cinco do livro de atas da escola local, onde deixou o seu parecer de verificação com as seguintes palavras,

Pela primeira vez tive a oportunidade de visitar hoje, neste grupo escolar, as classes do Professor Abílio Pires e Professora Alexandrina Vicente, tive grande prazer pelo entusiasmo que me proporcionou, disciplinas, boa vontade, entusiasmo, etc. Com esta satisfação lancei um lema para todos nós. (Querer é Poder). Ouvidor, 21 de abril de 1954.

-Assinatura ilegível-

Inspetor escolar.

Esta é uma mensagem elogiosa aos professores da nova escola. Destaca e imprime uma visão necessária à mesma: entusiasmo dos profissionais envolvidos, disciplina, boa vontade. Por outro lado, precisamos considerar o perigo da indicação política, prática usual nos grupos escolares. Para Souza (1998, p. 72), “o acesso e a ascensão na carreira não validavam a competência profissional certificada por critérios racionais como o concurso, e sim a indicação e o privilégio político e pessoal".

Dessa forma, decorridos cinco anos dos primeiros movimentos para o alcance da escola graduada em Ouvidor, a institucionalização da educação fundamental do local estava realizada por meio da implantação do primeiro Grupo Escolar na cidade. Cabe, portanto, verificar na sequência, como se deu a sua aceitação, uso e outras tramas voltadas para a sua permanência e eficácia. A interpretação e a análise das fontes existentes e depoimentos dos participantes nortearam o prosseguimento da reconstrução de sua história.

\section{AS MAZELAS E O PODER FRENTE À INSTRUÇÃO PÚBLICA DE OUVIDOR}

A história da primeira escola primária graduada do município de Ouvidor, na perspectiva de ex-professores, especialmente, trouxe consigo um passado carregado de dores, rancores, desentendimentos e segredos conservados nas amarras dos corações que muitas vezes passaram por humilhações e tiveram que lutar para exercer seu trabalho dentro da instrução pública do município.

Para Ataíde (2006),

O encontro dessas duas condições favoráveis - relações amistosas e tecnologia - propicia, possibilita ensejar depoimentos detalhados e densos, que mostram seu processo de construção, os diálogos geradores e o clima interativo e emocional que desencadeia os processos subjetivos (ATAÍDE, 2006, p. 313). 
O alcance das mazelas políticas de um lugar, nem sempre está depositado em fontes históricas convencionais. Para Pineau (2006) o fato de remexer o passado motiva uma releitura da história pessoal do indivíduo e aponta caminhos para a aquisição de uma identidade singular. A aproximação com os entrevistados foi fundamental para entendermos as políticas da história da educação de Ouvidor, um prisma adormecido, mas não esquecido. As narrativas que colhemos sobre o Grupo Escolar apontam muitas benesses para os moradores do município, mas, também, deixaram marcas de desapontamento.

Conforme vimos, foi após cinco anos de espera que aconteceu o segundo passo mais importante rumo à institucionalização do primeiro Grupo Escolar de Ouvidor, embora a instrução pública na modalidade de escola graduada tenha demorado ainda mais dois anos para avançar em seu aspecto organizacional, dentro dos padrões do modelo implantado desde 1949. Sob pressões e desentendimentos partidários vindos de todos os lados, o Grupo Escolar existia, mas não ia adiante. O poder centralizado nas mãos de poucos cidadãos favorecia o monopólio da contratação de professores para a escola.

E este movimento centralizado no poder político, trouxe alguns problemas. Nas entrevistas realizadas no dia 02 de março de 2015 com um ex-aluno ${ }^{12}$ e uma ex-professora, tanto na casa dele como na residência da ex-professora, eles contaram o mesmo fato. Disseram que existia uma prática no Grupo Escolar em que professoras, protegidas pela anuência de políticos, mantinham-se no quadro do grupo escolar como funcionárias "fantasmas", ou seja, eram contratadas, mas colocavam em seu lugar, substitutas para receberem parte de seus salários no final do mês. Umas porque não queriam trabalhar ou, em outros casos, por não terem idade para serem professoras, trabalhavam no nome de outras que jamais foram professoras. Assim, nomeavam uma, mas outra pessoa trabalhava em seu lugar ${ }^{13}$. A entrevistada citou os nomes de professoras que atuavam nesta situação, como também nos contou que a professora "favorecida" não tinha nenhum compromisso com o Grupo ou ânimo para a regência de sala, mas o seu nome era mantido e o contrato permanecia, sem a sua presença física entre aquelas que laboravam diariamente.

Os problemas advindos do poder político não cessaram por aí. A cidade, recém-emancipada, era modesta e poucas pessoas possuíam condições de se formar. Em Catalão, cidade vizinha, já existia, desde 1930, a escola normal no Colégio Nossa Senhora Mãe de Deus, administrado pelas irmãs agostinianas, que mantinha um sistema de bolsas de estudo e mensalidades altas. Mas a

\footnotetext{
${ }^{12}$ Vale ressaltar que para preservarmos os nomes dos sujeitos envolvidos na pesquisa, preferimos não citá-los neste artigo.

${ }^{13}$ Entrevista com ex-aluno I a ex-professora I.
} 
condição financeira das famílias de Ouvidor era pouca, restritas aos considerados ricos. As alunas que podiam pagar, muitas vezes não queriam estudar. Portanto, segundo informações de uma exprofessora da época, em entrevista realizada em Goiânia no dia 24 de fevereiro de 2014, quem tinha aptidão para o magistério geralmente não pertencia às famílias abastadas e quem podia se dar ao luxo de estudar não se interessava pelo assunto ${ }^{14}$.

O sistema de bolsas que existia no colégio era em troca de mão de obra. Na entrevista com os filhos do primeiro professor do município, professor Abílio, foi-nos revelado por uma de suas filhas ${ }^{15}$ que ela chegou a ir para o Colégio Nossa Senhora Mãe de Deus. Mas que infelizmente ela não tinha nenhuma aptidão para a cozinha e era obrigada a cozinhar. Conta que solicitou às freiras para deixá-la na limpeza sob a alegação de que não sabia e não gostava de cozinhar. Mas seu desejo não foi atendido, era forçada a cozinhar para pagar seus estudos, coisa que, segundo a família da jovem, ela não dava conta de fazer nem mesmo no ambiente familiar. Conta que no rodízio feito para as tarefas domésticas em casa com as suas irmãs ela sempre ficava com a limpeza e arrumação. Pelo depoimento dela própria, o fato de ser excelente aluna e tirar as melhores notas da sala não foi o suficiente para ser compreendida. Foi então que deixou de lado definitivamente o magistério. Interrompeu o seu sonho de se formar e retornou para casa dos pais com pesar. Na entrevista, com ares de melancolia, revelou que tinha muito gosto pelos estudos, era ávida por leitura e novos conhecimentos 16 e que conservava este hábito ainda hoje em sua velhice.

A realidade educacional de formação do professor não era precária só em Ouvidor, mas em todo estado de Goiás. Nepomuceno (1994, p. 62) retrata esta realidade relembrando que "a população urbana não recebia, na sua totalidade, sequer a instrução primária. [...] A educação secundária, nos moldes em que foi proposta [...] destinou-se de fato aos setores mais abastados da sociedade brasileira". A autora se refere à população urbana por excelência, pois a ela os benefícios educacionais disponíveis, públicos ou privados, teoricamente foram de mais fácil acesso, pois as escolas graduadas foram criadas inicialmente para os moradores das cidades. Dada a falta de incentivos aos habitantes rurais, proveniente, principalmente, da inexistência de transportes e meios de comunicação rudimentares e parcos, poucas pessoas se davam ao trabalho de saírem em busca de instrução.

Em linhas gerais, entre os muitos problemas encontrados que justificam a demora do primeiro grupo escolar de Ouvidor para se deslanchar, encontrava-se o fato de que a legislação do

\footnotetext{
${ }^{14}$ Entrevista com ex-professora I.

${ }^{15}$ Entrevista com ex-professora II.

${ }^{16}$ Entrevista com ex-professora II.
} 
momento exigia a formação no magistério para quem pretendesse ocupar o cargo de professor, sobretudo, o cargo de diretor da escola. O funcionário que conquistasse efetivamente esta vaga para diretor era responsável por fiscalizar e fazer funcionar as regras e as exigências convencionadas no bojo das escolas graduadas.

A maioria dos primeiros docentes do Grupo Escolar de Ouvidor iniciou sua atuação profissional apenas com a "formação" recebida pelas aulas do professor Abílio. Ele foi um autodidata e se instruiu pelo esforço próprio. De acordo com documentos de chamadas diárias dos alunos registrados nos livros e informações dos entrevistados, foi ele quem preparou a maioria destes professores para a regência de sala.

Quase todos os ex-alunos desse professor, que fizeram carreira no magistério, tiveram posteriormente a oportunidade de continuar seus estudos. Muitos saíram imediatamente do banco rude do barracão do mestre para o quadro negro escolar e ocuparam a posição de professores. Outros se prepararam em graus maiores e, pelas entrevistas e conversas sobre o tema, os envolvidos atribuem parte do que se tornaram ou ao que são hoje àquela distante escola de primeiras letras e aos ensinamentos e influência do professor do primário.

Nesta pesquisa, identificamos 27 docentes, ex-alunos do professor Abílio, vindos da escola isolada ou rural. Todos eles passaram pelo crivo da investigação documental para serem localizados como alunos ${ }^{17}$. Para serem localizados como professores, a pesquisa lançou mão, principalmente, de acervos e registros de duas escolas em Ouvidor: o Colégio Estadual Antônio Ferreira Goulart, onde alguns deles foram professores e até fundadores, e a Escola Estadual Dácio Amorim Fonseca, foco desta averiguação.

O rastreamento que fizemos dos nomes destes professores deu-se por conversas informais, pela utilização do livro de chamada, e até pelos meios de comunicação virtual. Muitos ainda estão vivos, o que nos possibilitou encontra-los. Aqueles já falecidos foram localizados através de fotos e informações de familiares.

17 Livro de registro da escola rural ou isolada $\mathrm{n}^{\circ}$ 01-acervo da escola pesquisada. Os alunos são: Aldo Pires Ribeiro (Filho do professor Abílio), Alexandrina Vicente da Rocha (Sobrinha do professor Abílio), Belgides Almeida Borges, Sebastião Pires Ribeiro (filho do professor Abílio), Julieta Domingos Caixeta, Maria do Rosário Silva (sobrinha do professor Abílio), Maria, Aparecida Silva (sobrinha do professor Abílio), Dirce Cândida Jorge (filha do professor Abílio), Maria de Fátima Amorim, Maria Pereira dos Santos, Wanda Torquato (sobrinha do professor Abílio), Neuza da Silva (sobrinha do professor Abílio), Maria Rosa da Silva, Eurípedes Ferreira Goulart, Lenita Pires Ribeiro (da Silva) (filha do professor Abílio), Jacira Vicente da Silva (sobrinha do professor Abílio), Maurílio Silvano Rosa, Ilton Domingos Cardoso, João Cezar Fonseca, Elda Firmino da Silva, Sarah Vicente da Rocha, Ruth Vicente da Rocha, Helena Firmino Cardoso, Enéas Torquato (sobrinho do professor Abílio), Maria Lúcia Ribeiro (filha do professor Abílio), Elvídia Vicente (sobrinha do professor Abílio). 
Trata-se, portanto, de ex-alunos de um professor formador que passaram pela profissão de professor, e, que, cada um com sua característica pessoal, tomaram seu rumo próprio no decorrer de sua atuação. Alguns se aposentaram na profissão de professor, outros escolheram outras profissões ou tiveram essa experiência paralela a outras atividades que já exerciam. Alguns aceitaram ser professores por vocação, outros por sugestão ou por se sentirem responsáveis pela atividade em algum momento de suas vidas. Muitos tiveram esta experiência docente "imediatamente" ao saírem da escola do professor Abílio, ou seja, sua única formação docente foram os ensinamentos daquele mestre. Outros puderam completar a sua formação antes de assumirem a docência e ainda há os que estudaram e se qualificaram depois de iniciarem a carreira docente.

O título destas páginas “As mazelas e o poder frente à instrução pública de Ouvidor” se deve ao fato de terem sido reveladas muitas mazelas políticas no percurso de vida docente dos figurantes acima, por eles ou pelas pessoas com as quais conversamos para chegarmos à sua formação. Memórias que ainda hoje faz infeliz quem delas se recordam e mencionam. Durante uma entrevista em particular, uma das participantes emocionou-se e chegou aos prantos quando teve que revelar a sua saga e como teria sido prejudicada pelas ações do poder político local.

Alguns desgostos mereceram destaque e foram citados, outros nem tanto, fato é que a interferência do "poder instituído"18 sempre determinou quem seriam os responsáveis pela instrução do povo em Ouvidor. As professoras do grupo escolar Dr. Pedro Ludovico, eram convidadas e selecionadas pela "amizade", "partidarismo" e "protecionismo", ou seja, por pura indicação política.

A grande maioria dos professores acabava por gostar do que faziam e se dedicavam no desempenho de suas funções, assim tornavam o grupo escolar em uma instituição onde as pessoas eram acreditadas e levadas em alta conta pela sociedade local.

A situação política era tão acirrada que em uma das entrevistas, uma ex-diretora nos contou uma passagem engraçada. Ela foi nomeada para trabalhar no grupo, de surpresa. Escola esta que havia deixado para se casar. Segundo ela, ao ficar viúva em 1958, foi surpreendida com sua própria nomeação para voltar ao grupo escolar, sem mesmo ser consultada se pretendia voltar as atividades docentes, assim nos contou a entrevistada... "O compadre de meu pai, o seu Tonico ${ }^{19}$ não falou nada nem pra mim nem para o meu pai. Aí ele foi lá mostrar a nomeação que chegou e levou junto os

\footnotetext{
${ }^{18}$ O poder político incluído no recorte temporal da pesquisa, 1949 a 1971, em Ouvidor nem sempre era proveniente dos cargos investidos, mas, de oligarquias familiares que prevaleciam frente aos governantes.

${ }^{19}$ Um Goulart, maior líder político de Ouvidor na época.
} 
políticos de Catalão. Meu nome até ficou errado, deu muito trabalho para consertar. Ele colocou meu nome de solteira e eu já assinava o nome de casada" ${ }^{20}$. Diante dessa surpresa política, o sobrenome dela ficou errado porque não tiveram a curiosidade de saber dela, se ela tinha interesse no cargo, tão pouco foi pedido a ela os seus documentos pessoais para a citada nomeação. Ou seja, os políticos conseguiam nomear apenas com a indicação de um nome. Mas ela garantiu que aceitou o emprego, pois estava viúva com dois filhos para criar. Assim, sua nomeação chegou em boa hora, conforme seu depoimento.

Em contra partida, a perseguição política foi tanta na trajetória profissional de alguns professores, que, além de deixar marcas desagradáveis, os afastaram definitivamente da docência. Nas entrevistas realizadas com os primeiros professores do grupo, recebemos a informação de que a política local era acirrada e a prática do mandonismo funcionava e fazia exonerar as pessoas que eles não gostavam. Contam que este foi o motivo de desistência da carreira de alguns colegas ${ }^{21}$.

Citamos um relato em especial em que uma professora foi muitas vezes cortada da folha de pagamentos, sendo exonerada em Ouvidor por mais de uma vez. Assim, quando ia receber seu salário descobria que tinha trabalhado em vão. Reunia sua coragem e, mesmo sem recursos financeiros, ela se deslocava de trem de ferro até a capital para conseguir reverter a sua demissão injusta. $\mathrm{O}$ fato se sucedeu até que a mesma, desiludida, resolveu se transferir para Goiânia e mudar de profissão por puro descontentamento com o fato. Uma irmã dessa professora e outros seus familiares mostraram durante toda conversa para esta pesquisa um sentimento de mágoa e comoção que os persegue até os dias de hoje, capaz de desencadear prantos no momento da visita para a entrevista $^{22}$.

A transcrição abaixo mostra a forma assustada, perplexa e indecisa da professora 01 ao ser inquerida durante a entrevista,

Entrevistador: Tinha problemas políticos na época em Ouvidor?

Professora 01: Tinha. Tinha... Nossa!!! E como tinha!!!

(A entonação da voz foi de forte emoção e de lembranças vivas, indesejadas, que culminaram em choro sem revelar os acontecimentos).

Entrevistador: Quais eram os problemas políticos?

Professora 01: Uai era marcação em cima de funcionários né? Isso tinha demais.

\footnotetext{
${ }^{20}$ Entrevista com a ex-diretora II e Ex-professora III - Entrevista(a). Na entrevista ela cita o sobrenome, mas, resolvemos não citar, conforme dito na nota 12 , acima.

${ }^{21}$ Entrevista com ex-professora I e citado também na entrevista com a ex-diretora II.

${ }^{22}$ Entrevista com Ex-professora n ${ }^{\circ} 01$.
} 
Entrevistador: A senhora pode citar algum exemplo.

(Por alguns instantes houve um silencio constrangedor, como se o assunto fosse proibido. E inicialmente quem respondeu foi a sobrinha da professora, uma ex-moradora de Ouvidor, em um desabafo saído entre prantos).

Sobrinha da professora ${ }^{23}$ : Minha mãe!!! Minha mãe foi professora em Ouvidor, e o que eles puderam prejudicar ela, eles fizeram. Por isto que nós saímos de Ouvidor. E viemos embora para Goiânia.

Professora 01: Minha sobrinha me lembrou, foi um dos motivos que eu saí de Ouvidor. Por causa das perseguições. Foi por causa de perseguição que minha irmã veio pra Goiânia e nunca mais quis saber de lecionar e este foi o motivo pelo qual eu me mudei também.

(Ex-Professora no 01. Entrevista realizada em Goiânia em fevereiro de 2015)

Essa ocorrência, segundo conversas com outros entrevistados, não foi a única. Assim, o poder político estadual e local reforçava as mazelas que interditavam, ao lado da falta de recursos financeiros, para a consolidação do Grupo Escolar Pedro Ludovico Teixeira em Ouvidor. A exdiretora II, na entrevista realizada em Brasília, no dia 15 de setembro de 2015, recordou que a professora I, entrevistada anteriormente em Goiânia, sofreu sérias e tristes perseguições políticas.

A entrevista com a ex-diretora II revelou que, mesmo depois que a professora I se mudou com a família para Goiânia, teve que enfrentar as consequências do poder dos políticos de Ouvidor lá na capital. Contou detalhes da forma como a professora teria sido nomeada para um Grupo Escolar na capital, também por influência da amizade com a família de Pedro Ludovico. Segundo ela, a professora colaborava com as catequeses religiosas e teria tido essa oportunidade por ser catequista das crianças desta família.

Mas, ela nos disse que quando a sua conhecida e anteriormente colega no Grupo Escolar Pedro Ludovico em Ouvidor, iniciou o seu trabalho no Grupo Escolar de Goiânia, ela foi exonerada pelos "figurões políticos da família dos Goulart" de sua cidade natal. E por duas vezes esse processo se repetiu.

Certamente, essas ocorrências com a vida das professoras desacelerava o processo de institucionalização do Grupo Escolar Dr. Pedro Ludovico Teixeira. Os passos iniciais para a implantação do Grupo aconteceram durante o poderio da UDN (União Democrática Nacional), representada pela pessoa do governador Jerônimo Coimbra Bueno, que esteve à frente do Palácio de Goiás entre 1947 a 1950, sucedido por seu desafeto, Pedro Ludovico Teixeira, intitulado na política goiana como "defensor da modernidade e do desenvolvimento econômico" ${ }^{24}$, que foi eleito

\footnotetext{
${ }^{23}$ Uma sobrinha da Ex-professora I participou da sessão de entrevista, por estar, no dia, visitando a Tia.

${ }^{24}$ Esse título se deu pelo fato de que, após a Revolução de 1930 a política em Goiás foi marcada pela transição oligárquica. $\mathrm{O}$ poder caiadistas, grupo familiar que se mantinha no poder político em Goiás, foi substituído por Pedro
} 
governador pelo PSD, Partido Social Democrático, em coligação com o PTB, Partido dos Trabalhadores Brasileiros.

Para Britto (1980), Jerônimo Coimbra Bueno não realizou o Governo que se esperava devido a três motivos principais: "a sua inexperiência política, a situação econômico-financeira do pós-guerra e a oposição sistemática do PSD” (BRITTO, 1980, p. 167). A oposição do PSD foi tão acirrada ao governo Coimbra Bueno que se chegou ao cúmulo do governo não ter conseguido a aprovação por três anos consecutivos do orçamento do Estado. Imaginamos que essas divergências políticas estaduais e também as locais possam ter contribuído para que o governador, que enviou um ofício de fundação do Grupo Escolar de Ouvidor, não tenha conseguido concretizar a sua institucionalização, tão prontamente. Com os ânimos municipais contrários à contratação de novas professoras para o novo Grupo e os seus antigos professores sem formação no magistério, a realidade atropelava a necessidade do momento, adiando assim a concretização burocrática do Grupo Escolar.

Um longo período se passou até que um novo registro ocorresse com a escrita da segunda ata no livro existente nas fontes encontradas no Grupo Escolar. O livro de atas foi reutilizado em 1954 e deu continuidade à história da instituição anunciada há cinco anos. Sua permanência até este ponto ficou camuflada pelo tempo sem registros e sem muitas lembranças dos figurantes.

$\mathrm{Na}$ entrevista com a diretora I, ela recordou que lecionava no pré-primário neste período a convite do prefeito de Catalão. Um único fato relacionado a este período de cinco anos nos faz crer que ao ser construído o prédio com apenas duas salas ficou sem os espaços físicos exigidos aos imponentes grupos escolares da ocasião, ou seja, o edifício construído não dispunha de uma sala de aula para cada turma existente.

Pelos registros encontrados no local, o sucesso da escola não era atribuído ao fato de ser uma escola graduada, mas era proveniente do esforço de seus próprios professores, conforme evidenciamos anteriormente nos elogios do inspetor escolar, em abril de 1954.

Além da alternância e da disputa das oligarquias pelo poder em Goiás, não se pode negar que a falta de professores habilitados no magistério tenha sido outro entrave para a

Ludovico Teixeira, que foi nomeado por Getúlio Vargas como interventor em Goiás devido a sua combatividade à ordem anterior e às afinidades que seu concunhado, o médico mineiro Diógenes Magalhães, mantinha com Vargas. $\mathrm{O}$ ludoviquismo se manteve por 15 anos consecutivos à frente do executivo estadual quando, além da fundação de Goiânia, construiu a rodovia que ligava a nova capital à Rio Verde, à Usina Rochedo, destinada a fornecer força e luz a Goiânia, à ponte sobre o rio Paranaíba, na divisa com Minas Gerais. Assim o perfil modernizador do político emprestou-lhe o título. Ver em (RODRIGUES, 2009). 
institucionalização definitiva do Grupo Escolar Dr. Pedro Ludovico. O lugar era pequeno, seu povo humilde e os recursos financeiros escassos. A maioria das experiências escolares dos primeiros professores do Grupo Escolar aconteceu no interior de suas casas ou nas escolas isoladas. Foram leigos que se fizeram docentes pelo esforço pessoal e enorme vontade de vencer. Além do mais, a história revela que a tomada de decisão para "deixar entrar" nos domínios políticos da cidade, pessoas estranhas, ou seja, professores que viriam de outros lugares não foi tarefa fácil para o prefeito da época. A consciência de que para que a escola graduada se instalasse com seus recursos e modernidade, definitivamente no Grupo Escolar de Ouvidor, abalou relacionamentos políticos e dividiu opiniões entre os dirigentes políticos na época da família Goulart.

De acordo com nossos estudos, percebemos que na maioria dos lugares por onde a implantação da escola graduada chegava havia uma resistência tácita no sentido de preservar o conhecido e manter os hábitos e costumes dos docentes leigos.

\section{CONSIDERAÇÕES FINAIS}

Sobre o ideal da república, Souza (1998) explica que: “a crença do poder redentor da educação pressupunha a confiança na instrução como elemento (co) formador dos indivíduos. [...] a educação foi atrelada a cidadania e, dessa forma, foi instituída a sua Imprescindibilidade para a formação do cidadão". (SOUZA, 1998, p.26).

A esperança na educação era tanta que a atribuição pelo atraso da sociedade brasileira era imposta unicamente à inexistência de políticas governamentais voltadas ao ensino público de qualidade e ao alcance de todos. Para os republicanos, as inovações didático-pedagógicas almejadas para o novo ensino primário seriam capazes de solucionar as mazelas que impediam o desenvolvimento econômico e todo o progresso nacional. Souza (1998, p. 24-26) explica que "nos projetos republicanos paulistas a educação tornou-se uma estratégia de luta, um campo de ação política, um instrumento de interpretação da sociedade brasileira e o enunciado de um projeto social".

No Brasil, as salas agrupadas e graduadas, retrato das multisalas praticadas no exterior, aparecem 23 anos após o processo ter iniciado na Inglaterra:

A criação dos grupos escolares surge, portanto, no interior do projeto político republicano de reforma social e de difusão da educação popular - uma entre várias medidas de reforma da instrução pública no estado de São Paulo, implementadas a partir de 1890 [...] ajudou a produzir uma nova cultura escolar, repercutiu na cultura da sociedade [...] Ainda, generalizou no âmbito do ensino público muitas práticas 
escolares em uso nas escolas particulares e circunscritas a um grupo social restrito - as elites intelectuais, políticas e econômicas (SOUZA, 1998, p. 29).

Institucionalizados no território nacional, os grupos escolares seguiam uma tendência difundida no mundo todo, sempre resguardando as particularidades de cada nação. Nessa conjuntura, as escolas reunidas passaram a ser a alma dos centros urbanos também no Brasil. Assim, para o combate à ignorância as escolas de primeiras letras existentes até então cedem lugar ao novo modelo de ensino, marcado por um jeito moderno e diferenciado, e entram em cena os grupos escolares.

Para Faria Filho (2000, p. 31), “a criação dos grupos escolares era defendida não apenas para organizar o ensino, mas como forma de reinventar a escola, objetivando tornar mais efetiva a sua contribuição aos projetos de homogeneização cultural e política da sociedade (e dos sujeitos sociais)". Para ele, esta mudança também significava: “organizar o ensino, suas metodologias e conteúdo; formar, controlar e fiscalizar a professora; adequar espaços e tempos ao ensino; repensar a relação com as crianças, famílias e com a própria cidade” (FARIA FILHO, 2000, p. 31).

A reafirmação da escola como instituição fundamental para alcance das propostas neste plano revolucionário não aconteceu de imediato, ou seja, após a Proclamação da República, mesmo estando expresso na Constituição, no artigo 35, que a reforma do ensino público seria iniciativa e responsabilidade do Congresso Nacional. A implantação dos primeiros grupos escolares, que significou o meio das mudanças tão esperadas pelos brasileiros republicanos, deu-se pelas circunstâncias favoráveis no Estado de São Paulo. Um dos motivos que atraiu a expressão de que Itu foi o "berço da República", a "Roma brasileira", dado ao seu engajamento político e desenvolvimentista, segundo Marçola, (2014), foi a implantação próspera das primeiras escolas graduadas no Brasil, o que encantou a nação brasileira. Cesário Motta Junior, então secretário do Interior paulista, abriu espaço e provocou admiração nos outros estados com o sucesso alcançado pelos primeiros grupos escolares institucionalizados em Itu, o Grupo Cesário Motta e o Grupo Escolar Queiroz Telles. Estas escolas se tornaram cobiçadas por outros estados por representarem uma moderna forma para a educação pública da época. Foi neste contexto que gradativamente o modelo se disseminou pelo Brasil e fez com que cada Estado arcasse com a responsabilidade de buscar para seus territórios aquela novidade promissora.

No livro "Escola Primária na Primeira República (1889-1930): subsídios para uma história comparada", os autores confirmam que: 
Vários estados brasileiros buscaram implantar essa escola primária moderna ao longo da primeira República: em São Paulo em 1893, no Rio de Janeiro, em 1897; no Maranhão e no Paraná, em 1903; em Minas Gerais, em 1906; na Bahia, Rio Grande do Norte, Espírito Santo e Santa Catarina , em 1908, no Mato Grosso, em 1910, Sergipe, em 1911, no território do Acre, em 1915, na Paraíba em 1916, em Goiás, em 1918, e no Piauí em 1922 (ARAUJO; SOUZA e PINTO, 2012, p. 10).

Para Pinto (2012), as bases de um sistema educacional moderno com as novas concepções de escola, nos moldes da educação seriada dos grupos escolares, já haviam sido lançadas em Goiás desde 1917. Afirma também que as escolas isoladas foram mantidas na nova legislação educacional de 1918 e permaneceram até 1930. O Estado tinha um precário e incipiente sistema educacional de mestre único, ou seja, todos os alunos e séries frequentavam a mesma sala e desfrutavam dos ensinamentos de um único professor. Como era a única prática existente e possível, as escolas isoladas não foram banidas de um momento para o outro, embora Ouvidor ocupasse uma localização geográfica privilegiada em relação às demais regiões do interior de Goiás. As pretensões e as influências políticas que marcaram a história da sua educação não foram suficientes para aligeirar o processo de inauguração e funcionamento do grupo escolar. A falta de escolaridade do povo era um problema nacional na grande maioria dos estados brasileiros e isso também marcou fortemente a institucionalização do Grupo Escolar Dr. Pedro Ludovico Teixeira no município de Ouvidor, que na época era apenas um povoado.

Em nenhum momento, nesta pesquisa sobre a história do primeiro grupo escolar de Ouvidor-GO, tivemos a pretensão de anunciar uma atividade de impacto, cujas investigações seriam uma novidade iminente. Mas, ocorreu que a região explorada, o sudeste goiano, se enquadrou como campo de pesquisa não esgotado dentro do sentido proposto. Percebemos que a região do sudeste de Goiás ainda dispõe de uma gama acentuada de fontes e locais que podem ser investigados, imprimindo Goiás e seus municípios, por este veio, como parte da história da educação no Brasil.

Reconhecemos que as pesquisas sobre instituições e em especial a dos grupos escolares, não se constituem em uma novidade nos estudos recentes de história da educação. Contudo, não se pode dizer o mesmo quando se pensa na história da educação em Goiás. É, neste sentido, que imaginamos a relevância das narrativas sobre a institucionalização do primeiro Grupo Escolar Dr. Pedro Ludovico Teixeira, do então distrito (hoje município) de Ouvidor.

A mesma autora acima citada (PINTO, 2012) enumera os diversos problemas apresentados nos relatórios dos governantes de Goiás na época da implantação dos grupos escolares. Coloca junto à falta de escolaridade dos professores goianos, citado como um sétimo e grave entrave para $\mathrm{o}$ pleno desenvolvimento da educação do Estado, a falta de compromisso e responsabilidade dos 
mestres. Em comum as essas constatações da pesquisadora, percebemos que em Ouvidor as amarras políticas favoreceram a permanência de profissionais que além de serem desqualificados para as suas funções, pela falta de um diploma, não apresentavam compromisso sério com seus alunos. Faltavam e abusavam de sua condição de mestre sobre a proteção de movimentos políticos que lhes eram favoráveis.

Mas, também encontramos o contrário, vimos o caso do primeiro professor que era analfabeto e posteriormente foi o responsável pela formação de muitos outros educadores. As intrigas vividas entre o poder político e as exigências legais comprometeram a permanência de pessoas com o avanço da educação em Ouvidor, mas, retardou a legalização definitiva da escola criada. Entre 1949 e 1962, longos anos de instabilidade e divergências políticas permearam a consolidação definitiva e conclusa do grupo Escolar na cidade. Os professores leigos se mantiveram dispostos a romper as barreiras de uma estrutura modesta e de uma formação considerada inadequada para os padrões dos grupos escolares em favor da nova conquista. Muitos deles estudaram e se formaram. Outros por motivos variados abandonaram a profissão. Mas, o fato concreto é que, enquanto não foram aceitas profissionais formadas no curso normal, o grupo escolar se manteve afastado das novidades instituídas com as escolas graduadas.

Porém, as mazelas decorrentes da manutenção do poder e os interesses políticos diversos estavam presentes também no município de Ouvidor de forma acentuada. E com o anúncio do Grupo Escolar, as disputas mantiveram os professores leigos enquanto deram conta de impedir a chegada das professoras normalistas. Por outro lado, os educadores locais não tinham condições de se formarem no tempo exigido pela legislação.

A implantação do Grupo Escolar Dr. Pedro Ludovico Teixeira representou a chegada da nova modalidade de educação no distrito de Ouvidor, que manteve uma proximidade temporal razoável em relação aos grupos escolares de outros lugares no Estado de Goiás. Durante o percurso da investigação, as revelações do povoado que abrigava o Grupo Escolar estudado, voltaram se para a sua transformação em distrito (Ouvidor) e assim descortinou acontecimentos que não puderam ser desprezados para a história da instituição. Uma coisa estava ligada a outra. O momento em que o povoado se tornava Distrito teve relação com a chegada dos trilhos e com a construção da estação ferroviária, pois, com eles, houve um crescimento na população e um desenvolvimento local que foi mencionado, ao alcance, também, da memória dos participantes. Mas, a implantação do Grupo escolar também teve influência na organização do distrito e com isto a conquista da emancipação política. 
A criação, portanto, do primeiro grupo escolar em Ouvidor-GO esteve relacionado à expansão do capitalismo no centro sul brasileiro atingindo diferentes dimensões na vida dos moradores de sul e sudeste de Goiás (NEPOMUCENO, 1994). O crescimento populacional foi crescente nessas regiões, como também surgiu a necessidade de estradas e meios de escoação da produção agrícola. E a estrada de ferro foi uma dessas alternativas que ligou Goiás ao sul do Brasil. Foi assim que, segundo os entrevistados, os trilhos trouxeram para Ouvidor pessoas de lugares mais desenvolvidos, portadores de diplomas, que ao conviverem com a população nativa conquistaram respeito e participaram das políticas locais. Puderam auxiliar na emancipação política do distrito e apoiavam a educação local, conforme iam sendo solicitados. Em especial, conta-se que um dos farmacêuticos vindo de Minas gerais para Ouvidor, teria sido responsável pela evolução didática do primeiro professor do Grupo Escolar. Pessoa considerada como um bom mestre na memória de muitos participantes da pesquisa: Professor Abilio José Pires. Mas, essas são histórias para outras reflexões sobre a história da educação no sudeste de Goiás.

\section{REFERÊNCIAS}

ARAÚJO, J. C. S.; SOUZA, R. F. de; PINTO, R. N.. (Org.). ESCOLA PRIMÁRIA NA PRIMEIRA REPÚBLICA (1889-1930): subsídios para uma história comparada. 01 ed. Araraquara/SP: Junqueira\&Marin Editores, 2012

ATAÍDE, Y. D. B. História oral e construção da história de vida. In: SOUZA, E. C.; ABRAHÃO, M. H. M. B. (Orgs.) Tempos, Narrativas e Ficções: a invenção de si. Porto Alegre: EDPUCRS; Salvador: EDUNEB, 2006. p. 312 a 344.

BOLÍVAR. A. Narrar La Organización Educativa: Memoria Institucional Y Constitucion de La Identidad. In: ABRAHÃO. M. H. M. B. BOLIVAR. A. (org.) La Investigacion (Auto) Biográfica Em Educación: Miradas Cruzadas Entre o Brasil Y Espana. Granada: EUG; Porto Alegre; EDIPUCRS, 2014.

Bretas. G. F. História da Instrução Publica em Goiás. Coleção Documentos Goianos no 27. Goiânia Goiás. CEGRAF/UFG, 1991.

BRITTO, F. de. Memórias de outro tempo (1904-1959). Goiânia: Abertura, 1980.

FARIA FILHO, L. M. Dos pardieiros aos palácios: cultura escolar em Belo Horizonte na Primeira República. Passo Fundo: UPF, 2000.

NEPOMuCEnO, M. de A. A Ilusão Pedagógica - 1930-1945: estado, sociedade e educação em Goiás. Goiânia: Editora da UFG, 1994.

NOSELLA, P.; BUFFA, E. Instituições escolares: porque e como pesquisar. Campinas: Ed. Alínea, 2009.

PINEAU, G. As histórias de vida como artes formadoras da existência. In: SOUZA, E. C.; ABRAHÃO, M. H. M. B. (Orgs.) Tempos, Narrativas e Ficções: a invenção de si. Porto Alegre: EDPUCRS; Salvador: EDUNEB, 2006. p. 41 a 60.

PINTO, R. N. SOUZA, R. F.; ARAUJO, J. C. A Escola Primária e o Ideário Republicanista nas Mensagens dos Presidentes de Estado: Investigações comparativas. In: SOUZA, R. F. (Org.); SILVA, V.L.G. (Org.) SÁ, E. F. (Org.). Por uma teoria e uma história da escola primária no Brasil: investigações comparadas sobre a escola graduada (18701930). 1ed.CUIBA: Ed. UFMT, 2013, v. 01, p. 105-145.

PINTO, R. N. Escola primária em Goiás na Primeira República: tensões e distensões de um jogo de empurra. In: ARAÚJO, J. C. S.; SOUZA, R. F. de; PINTO, R. N. (Org.). ESCOLA PRIMÁRIA NA PRIMEIRA REPÚBLICA (1889-1930): subsídios para uma história comparada. 01 ed. Araraquara/SP: Junqueira\&Marin Editores, 2012, v. 01, p. 300-328. 
PINTO, R. N. Escola primária em Goiás (1930-1960): entre cidades e fazendas, a escolarização como dispositivo de integração nacional. In: VII CONGRESSO BRASILEIRO DE HISTÓRIA DA EDUCAÇÃ̂, 2013, CUIABÁ. VI Congresso Brasileiro de História da Educação. CUIABÁ: SBHE/UFMT, 2013. v. 1. p. 1-10.

RODRIGUES, Fernando Rocha. Pedro Ludovico, o Democrata Modernizador ou o Coronel da Modernidade? Revista FACER, v. 09, p. 018-126, 2009.

SAVIANI, D. Instituições escolares no Brasil: Conceito e reconstrução histórica. In: NASCIMENTO, M. I. M. [et. al.] (Orgs.) Instituições escolares no Brasil. Campinas, SP: Autores Associados: HISTEBR; Sorocaba, SP: Uniso; Ponta Grossa, PR: UEPG, 2007.

SOUZA, R. F. de. Templos de Civilização: a implantação da escola primária graduada no Estado de São Paulo. São Paulo: Fundação Editora a Unesp, 1998.

\section{RESUMO}

Cresce no território nacional pesquisas sobre história das instituições escolares no Brasil. Porém, há ainda uma grande lacuna nessas pesquisas, especialmente quando se diz respeito à história de instituições no interior do País. Este texto objetiva historicizar o processo de institucionalização do primeiro Grupo Escolar da Cidade de Ouvidor - GO, de 1949 a 1971, Grupo Escolar Dr. Pedro Ludovico Teixeira. A metodologia utilizada foi a pesquisa sobre narrativas tanto escritas, fontes documentais do referido Grupo Escolar, bem como narrativas orais, de ex-professores, ex-diretores e ex-alunos. Verificamos que o processo de institucionalização esteve relacionado às disputas políticas estaduais, bem como municipais, e, outro sim, à chegada lenta de professores formados no magistério, para implementar a escola graduada. Por fim, o cenário histórico educacional de Ouvidor - GO se aproxima das histórias de instituições escolares no Brasil, mas também se distancia das mesmas, na medida em que envolve personagens regionais específicos.

Palavras-Chave: História das instituições escolares; Ouvidor - GO; institucionalização escolar.

\section{SCHOOL INSTITUTIONALIZATION OF THE CITY OF OUVIDOR-GO- 1949-1971}

ABSTRACT: Research on the history of school institutions in Brazil grow in the country. However, there is still a big gap in the polls, especially when it relates to the institutions history of country interior. This paper seeks historicizing the institutionalization process of the first School Group of the City of Ouvidor - GO from 1949 to 1971, the School Group Dr. Pedro Ludovico Teixeira. The methodology used was the research on narratives both written, documentary sources of referred School Group, as well as oral narratives of former teachers, former directors and former students. We found that the institutionalization process was related to the state political disputes, as well as municipal and, furthermore, the slow arrival of teachers trained in teaching to implement the graduate school. Finally, the educational background scenario of Ouvidor - GO approaches the stories of educational institutions in Brazil, but also distances of them, because involves specific regional characters.

Keywords: history of school institutions; Ouvidor - GO; school institutionalization 